\title{
Alleviation of Lead Toxicity by 5-Aminolevulinic Acid Is Related to Elevated Growth, Photosynthesis, and Suppressed Ultrastructural Damages in Oilseed Rape
}

\author{
Tian Tian, ${ }^{1}$ Basharat Ali, ${ }^{1}$ Yebo Qin, ${ }^{2}$ Zaffar Malik, ${ }^{3}$ Rafaqat A. Gill, ${ }^{1}$ Shafaqat Ali, ${ }^{4}$ \\ and Weijun Zhou ${ }^{1}$ \\ ${ }^{1}$ Institute of Crop Science and Zhejiang Key Laboratory of Crop Germplasm, Zhejiang University, Hangzhou 310058, China \\ ${ }^{2}$ Crop Production Bureau, Zhejiang Provincial Department of Agriculture, Hangzhou 310020, China \\ ${ }^{3}$ College of Environmental and Resource Sciences, Zhejiang University, Hangzhou 310058, China \\ ${ }^{4}$ Department of Environmental Sciences, Government College University, Faisalabad 38000, Pakistan
}

Correspondence should be addressed to Weijun Zhou; wjzhou@zju.edu.cn

Received 11 November 2013; Accepted 24 December 2013; Published 11 February 2014

Academic Editor: Qaisar Mahmood

Copyright (C) 2014 Tian Tian et al. This is an open access article distributed under the Creative Commons Attribution License, which permits unrestricted use, distribution, and reproduction in any medium, provided the original work is properly cited.

Lead $(\mathrm{Pb})$ is a widely spread pollutant and leads to diverse morphological and structural changes in the plants. In this study, alleviating role of 5-aminolevulinic acid (ALA) in oilseed rape (Brassica napus L.) was investigated with or without foliar application of ALA $\left(25 \mathrm{mg} \mathrm{L}^{-1}\right)$ in hydroponic environment under different Pb levels $(0,100$, and $400 \mu \mathrm{M})$. Outcomes stated that plant morphology and photosynthetic attributes were reduced under the application of $\mathrm{Pb}$ alone. However, ALA application significantly increased the plant growth and photosynthetic parameters under $\mathrm{Pb}$ toxicity. Moreover, ALA also lowered the $\mathrm{Pb}$ concentration in shoots and roots under $\mathrm{Pb}$ toxicity. The microscopic studies depicted that exogenously applied ALA ameliorated the $\mathrm{Pb}$ stress and significantly improved the cell ultrastructures. After application of ALA under $\mathrm{Pb}$ stress, mesophyll cell had well-developed nucleus and chloroplast having a number of starch granules. Moreover, micrographs illustrated that root tip cell contained well-developed nucleus, a number of mitochondria, and golgi bodies. These results proposed that under 15-day Pb-induced stress, ALA improved the plant growth, chlorophyll content, photosynthetic parameters, and ultrastructural modifications in leaf mesophyll and root tip cells of the B. napus plants.

\section{Introduction}

Environmental pollutants like heavy metals are toxic even at low concentration. Lead $(\mathrm{Pb})$ is amongst one of the most toxic pollutants which is not an essential nutrient for plants [1]. The contamination of $\mathrm{Pb}$ in environment is of major ecological alarm due to its long persistent nature that causes risk effects on human health through the food chain [2]. Lead accumulation is recognized to cause highly deleterious effects on growth and yield of plants [3]. It was reported that $\mathrm{Pb}$ significantly suppressed the root elongation in mesquite (Prosopis sp.) [4]. Plant growth retardation under $\mathrm{Pb}$ stress may be due to nutrient imbalance, disturbed photosynthesis, obstacle in electron transport system, and inadequate levels of carbon dioxide due to stomatal closure $[5,6]$. It is documented that $\mathrm{Pb}$ prohibits the nutrient uptake, net photosynthetic rate, and cellular respiration and causes damage to cell membrane [7]. It has been stated that photosynthesis inhibition is a wellrecognized symptom of $\mathrm{Pb}$ toxicity [8]. Lately, Jiang and Liu [9] proposed that exposure of $\mathrm{Pb}$ for $72 \mathrm{hr}$ to Allium sativum roots induced ultrastructural changes, that is, loss of cristae, mitochondrial swelling, dictyosomes, endoplasmic reticulum vacuolization, impairment into lamellar organization of the chloroplast, and cell division [10]. Thus, it is very important to exploit the potential of oilseed rape plant against $\mathrm{Pb}$ stress.

The plant growth regulators (PGRs) are mostly used to alleviate abiotic stress in plants. The 5-aminolevulinic acid (ALA), one of the most vital plant growth regulators, 
is an essential precursor for the formation of tetrapyrroles like protochlorophyllide (which is converted into chlorophyll when exposed to light) [11]. In our previous research, ALA had been found to promote growth of $B$. napus under cadmium (Cd) stress [12, 13]. Similarly, Zhang et al. [14] applied the ALA in oilseed rape plants and suggested that it alleviates the toxicity of herbicides. Wang et al. [15] delineated that treatment of $B$. campestris L. with ALA yielded a positive effect on the seedlings growth. Furthermore, ALA improved the plant growth in terms of biomass of different plant parts under salinity-stress conditions [16] and ALA is the major photosynthetic light harvesting pigment [17]. Recently, it has been documented that root morphology was exalted under the combined treatment of ALA and Cd in B. napus [18].

It is evident from a number of previous reports that ALA, like other known PGRs, is effective in counteracting the injurious effects of various abiotic stresses on plants, but the mechanisms how it regulates growth under stressful cues are not fully elucidated yet. The present research was undertaken to investigate the changes in the level of plant growth, photosynthetic activity, and $\mathrm{Pb}$ uptake due to ALA application on $B$. napus under $\mathrm{Pb}$ stress. It is hypothesized that ALA regulates the growth, photosynthetic attributes, chlorophyll contents, and ultrastructural changes under $\mathrm{Pb}$ stress conditions in B. napus L.

\section{Materials and Methods}

2.1. Plant Material and Treatments. For the experiment, $B$. napus L. cv. ZS 758 seeds were obtained from Zhejiang University. The seeds were grown in plastic pots $(170 \mathrm{~mm} \times$ $220 \mathrm{~mm}$ ) which were filled with peat moss. At five-leaf stage, uniform seedlings were plugged into plate holes on plastic pots (five plants per pot) containing Hoagland nutrient solution [19], in which concentration of $\mathrm{KH}_{2} \mathrm{PO}_{4}$ was kept as minimum as $0.01 \mathrm{mM}$ in order to avoid precipitation of lead $(\mathrm{Pb})$. The composition of Hoagland nutrient solution was as follows (in $\mu \mathrm{mol} \mathrm{L}^{-1}$ ): $3000 \mathrm{KNO}_{3}, 2000 \mathrm{Ca}\left(\mathrm{NO}_{3}\right)_{2} \cdot 4 \mathrm{H}_{2} \mathrm{O}$, $1000 \mathrm{MgSO}_{4} \cdot 7 \mathrm{H}_{2} \mathrm{O}, 10 \mathrm{KH}_{2} \mathrm{PO}_{4}, 12 \mathrm{FeC}_{6} \mathrm{H}_{6} \mathrm{O}_{7}, 500 \mathrm{H}_{3} \mathrm{BO}_{3}$, $800 \mathrm{ZnSO}_{4} \cdot 7 \mathrm{H}_{2} \mathrm{O}, 50 \mathrm{MnCl}_{2}, 300 \mathrm{CuSO}_{4} \cdot 5 \mathrm{H}_{2} \mathrm{O}$, and 100 $\mathrm{Na}_{2} \mathrm{MoO}_{4}$. The $\mathrm{pH}$ was maintained at 5.5 with $1 \mathrm{M}$ solution of $\mathrm{NaOH}$ or $\mathrm{HCl}$. Aeration was given continuously through air pump in the nutrient medium. The nutrient solution was changed after every four days.

After two weeks, solutions were supplied to required $\mathrm{Pb}$ as $\mathrm{Pb}\left(\mathrm{NO}_{3}\right)_{2}$ concentration $(0,100$, and $400 \mu \mathrm{M})$ and simultaneously plants were sprayed with an aqueous solution of ALA (Cosmo Oil Co. Ltd., Japan) at concentrations of 0 and $25 \mathrm{mg} \mathrm{L}^{-1}$ ALA. The spray was done on the lower as well as the upper leaf surfaces with a hand-held atomizer [20]. ALA was applied as a foliar spray at a rate of $20 \mathrm{~mL}$ of formulated solution/plant. After the five days of first spray, subsequent application was followed. The control plants were sprayed with distilled water. Fifteen days after treatment, all morphological data and photosynthetic gas exchange parameters were recorded. Samples for chlorophyll contents and microscopic studies of leaf mesophyll and root tip cell were collected as described next.
2.2. Plant Morphological Parameters. After 15 days of treatment, harvested plants were separated into leaf, stem, and root. The plant height, stem length, root length, and leaf area were recorded simultaneously. Root surface area, volume, diameter, and number of root tips of randomly selected plants were determined using root automatism scan apparatus (MIN MAC, STD1600 ${ }^{+}$), equipped with WinRHIZO software offered by Regent Instruments Inc.

2.3. Photosynthetic Attributes. Photosynthetic parameters were analyzed 15 days after treatment by LiCor-6400 portable photosynthesis system (Li-Cor Inc., Lincoln, NE, USA). All the photosynthetic attributes were measured on the intact topmost fully expanded leaf after $2 \mathrm{hr}$ of acclimatization in a growth cabinet, at a temperature of $18^{\circ} \mathrm{C}$ under a light intensity of $1,000 \mu \mathrm{mol} \mathrm{m}{ }^{-2} \mathrm{~s}^{-1}$, relative humidity of $60 \%$, and took at least eight readings per treatment [21]. Chlorophyll contents in B. napus leaves were estimated according to Porra et al. [22] and Pei et al. [23].

2.4. Analysis of $\mathrm{Pb}$ Concentration. $\mathrm{Pb}$ contents in different plant parts were determined with the method of Hsu and Kao [24]. The tissue samples were dried at $65^{\circ} \mathrm{C}$ for $24 \mathrm{hr}$ and then ashed in Muffle furnace at $550^{\circ} \mathrm{C}$ for $20 \mathrm{hr}$. Then the ash incubated was with $31 \% \mathrm{HNO}_{3}$ and $17.5 \% \mathrm{H}_{2} \mathrm{O}_{2}$ at $70^{\circ} \mathrm{C}$ for about $2 \mathrm{hr}$, and then this was dissolved in distilled water. $\mathrm{Pb}$ concentration was determined by using spectrophotometer (AA-6800, Shimadzu Co. Ltd., Japan).

2.5. Microscopic Study. After 15 days of treatment, topmost leaf fragments without veins and root tips were collected from randomly selected plants and then fixed overnight in $4 \%$ glutaraldehyde (v/v) in 0.1 M PBS (sodium phosphate buffer, $\mathrm{pH}$ 7.4) followed by three times washing with the same PBS. Samples were postfixed in $1 \% \mathrm{OsO}_{4}$ (osmium (VIII) oxide) for $1 \mathrm{hr}$, washed three times in $0.1 \mathrm{M}$ PBS ( $\mathrm{pH}$ 7.4) with $10 \mathrm{~min}$ interval between each washing. Then with 15-20 min interval, the samples were dehydrated in a graded series of ethanol $(50 \%, 60 \%, 70 \%, 80 \%, 90 \%, 95 \%$, and $100 \%)$ and at the end washed by absolute acetone for $20 \mathrm{~min}$. The samples were then infiltrated and embedded in Spurr's resin overnight. After heating at $70^{\circ} \mathrm{C}$ for $9 \mathrm{hr}$, ultrathin sections $(80 \mathrm{~nm})$ of specimens were prepared and mounted on copper grids for viewing by a transmission electron microscope (JEOL TEM$1230 \mathrm{EX})$ at an accelerating voltage of $60.0 \mathrm{kV}$.

2.6. Statistical Analysis. The SPSS version 16.0 (SPSS, Chicago, IL, USA) was used to analyze the data. A two-way variance analysis (ANOVA) was carried out, followed by the Duncan's multiple range test.

\section{Results}

3.1. ALA Ameliorated Pb-Induced Inhibition of Plant Growth. The data regarding plant height, stem length, root length, and number of leaves per plant under different treatments of $\mathrm{ALA}$ and $\mathrm{Pb}$ is given in Table 1 . The results showed that $\mathrm{Pb}$ toxicity significantly inhibited the plant growth as compared 
TABLE 1: Effects of treatments of 5-aminolevulinic acid (ALA) $\left(\mathrm{mg} \mathrm{L}^{-1}\right)$ and lead $(\mathrm{Pb})(\mu \mathrm{M})$ on plant height $(\mathrm{cm})$, stem length ( $\left.\mathrm{cm}\right)$, root length $(\mathrm{cm})$, and leaf area $\left(\mathrm{cm}^{2}\right.$ plant $\left.^{-1}\right)$ of Brassica napus $\mathrm{L}$.

\begin{tabular}{cccccc}
\hline \multirow{2}{*}{ ALA conc. } & \multirow{2}{*}{ Pb conc. } & \multicolumn{4}{c}{ Mean values and their relative increase/decrease over respective controls } \\
& & Plant height & Stem length & Root length & Leaf area \\
\hline \multirow{3}{*}{0} & $44.73 \pm 2.83^{\mathrm{a}}(0)$ & $14.46 \pm 0.94^{\mathrm{a}}(0)$ & $18.22 \pm 1.17^{\mathrm{b}}(0)$ & $325.66 \pm 14.62^{\mathrm{a}}(0)$ \\
& 100 & $37.47 \pm 2.53^{\mathrm{b}}(-16.22)$ & $9.58 \pm 0.71^{\mathrm{c}}(-33.74)$ & $17.54 \pm 1.27^{\mathrm{bc}}(-3.73)$ & $223.09 \pm 14.59^{\mathrm{c}}(-31.49)$ \\
& 400 & $26.73 \pm 2.11^{\mathrm{c}}(-40.24)$ & $6.35 \pm 0.58^{\mathrm{d}}(-56.08)$ & $11.55 \pm 0.94^{\mathrm{d}}(-36.61)$ & $174.25 \pm 11.53^{\mathrm{d}}(-46.49)$ \\
\hline \multirow{4}{*}{25} & 0 & $45.35 \pm 2.69^{\mathrm{a}}(+1.38)$ & $13.50 \pm 0.81^{\mathrm{ab}}(-6.06)$ & $18.65 \pm 1.31^{\mathrm{b}}(+2.36)$ & $333.14 \pm 12.98^{\mathrm{a}}(+2.31)$ \\
& 100 & $42.50 \pm 2.06^{\mathrm{a}}(+13.42)$ & $12.26 \pm 0.79^{\mathrm{b}}(+27.97)$ & $21.49 \pm 1.73^{\mathrm{a}}(+22.51)$ & $312.90 \pm 13.65^{\mathrm{a}}(+40.25)$ \\
& 400 & $37.51 \pm 1.00^{\mathrm{b}}(+40.32)$ & $10.42 \pm 0.73^{\mathrm{c}}(+64.09)$ & $15.39 \pm 1.03^{\mathrm{c}}(+33.24)$ & $265.66 \pm 13.27^{\mathrm{b}}(+52.45)$ \\
\hline
\end{tabular}

Values are the means of four replications $\pm \mathrm{SD}$. Variants are significant at $P \leq 0.05$.

TABLE 2: Effects of treatments of 5-aminolevulinic acid (ALA) $\left(\mathrm{mg} \mathrm{L}^{-1}\right)$ and lead $(\mathrm{Pb})(\mu \mathrm{M})$ on the root morphology of Brassica napus L.

\begin{tabular}{cccccc}
\hline \multirow{2}{*}{ ALA conc. } & \multirow{2}{*}{ Pb conc. } & \multicolumn{4}{c}{ Mean values and their relative increase/decrease over respective controls } \\
& & Root diameter $(\mathrm{cm})$ & Root surface area $\left(\mathrm{cm}^{2}\right)$ & Root volume $\left(\mathrm{cm}^{3}\right)$ & Number of root tips \\
\hline \multirow{3}{*}{0} & $0.92 \pm 0.17^{\mathrm{bc}}(0)$ & $237.44 \pm 13.15^{\mathrm{b}}(0)$ & $12.76 \pm 0.80^{\mathrm{b}}(0)$ & $1329.83 \pm 21.59^{\mathrm{c}}(0)$ \\
& 100 & $4.09 \pm 0.12^{\mathrm{d}}(-16.86)$ & $213.85 \pm 14.11^{\mathrm{c}}(-9.93)$ & $11.45 \pm 0.58^{\mathrm{c}}(-10.26)$ & $1293.25 \pm 21.78^{\mathrm{c}}(-2.75)$ \\
& 400 & $2.58 \pm 0.11^{\mathrm{e}}(-47.56)$ & $167.48 \pm 8.61^{\mathrm{d}}(-92.63)$ & $7.62 \pm 0.66^{\mathrm{d}}(-40.28)$ & $898.61 \pm 19.07^{\mathrm{e}}(-32.42)$ \\
\hline \multirow{4}{*}{25} & 0 & $5.34 \pm 0.18^{\mathrm{a}}(+8.53)$ & $264.71 \pm 11.83^{\mathrm{a}}(+11.48)$ & $13.11 \pm 0.37^{\mathrm{b}}(+2.74)$ & $1392.99 \pm 20.05^{\mathrm{b}}(+4.74)$ \\
& 100 & $5.11 \pm 0.10^{\mathrm{ab}}(+24.93)$ & $249.68 \pm 12.53^{\mathrm{ab}}(+16.75)$ & $14.99 \pm 0.69^{\mathrm{a}}(+30.91)$ & $1488.33 \pm 19.35^{\mathrm{a}}(+15.08)$ \\
& 400 & $4.74 \pm 0.23^{\mathrm{c}}(+83.72)$ & $193.78 \pm 11.33^{\mathrm{c}}(+15.70)$ & $10.68 \pm 0.61^{\mathrm{c}}(+40.15)$ & $1150.03 \pm 24.55^{\mathrm{d}}(+27.97)$ \\
\hline
\end{tabular}

Values are the means of four replications $\pm \mathrm{SD}$. Variants are significant at $P \leq 0.05$.

to the control. The $\mathrm{Pb}$ toxicity at higher level $(400 \mu \mathrm{M})$ visibly reduced the plant length by $40.24 \%$, shoot length by $56.08 \%$, root length by $36.61 \%$ and number of leaves per plant by $46.49 \%$ as compared to control plants. Foliar applied ALA at $25 \mathrm{mg} \mathrm{L}^{-1}$ significantly improved the plant growth parameters under $\mathrm{Pb}$ toxicity. Moreover, application of ALA alone did not show any change in the plant growth; rather, it alleviated the adverse effects of $\mathrm{Pb}$ under $\mathrm{Pb}$ stress conditions (Table 1). The effects of ALA and $\mathrm{Pb}$ at different treatments on root morphology of $B$. napus have been shown in Table 2. The data clearly demonstrated that root diameter, root surface area, root volume, and number of root tips significantly were reduced as $\mathrm{Pb}$ concentrations increased in the solution culture. Higher concentration of $\mathrm{Pb}(400 \mu \mathrm{M})$ alone significantly reduced the root diameter by $47.56 \%$, root surface area by $92.63 \%$, root volume by $40.23 \%$, and number of root tips by $32.42 \%$ in contrast to control plants. However, ALA increased the root morphology and this increase was in root diameter by $24.93 \%$ and $83.72 \%$, in root surface area by $16.75 \%$ and $15.70 \%$, in root volume by $30.91 \%$ and $40.15 \%$ and in number of root tips by $15.08 \%$ and $27.97 \%$ under different concentrations of $\mathrm{Pb}(100$ and $400 \mu \mathrm{M}$, resp.) as compared to their respective controls. Moreover, exogenous ALA alone significantly enhanced the root morphology except root volume as compared to control.

3.2. Photosynthetic Parameters. The data regarding chlorophyll attributes under different treatments of ALA and $\mathrm{Pb}$ are expressed in Table 3. The results showed that $\mathrm{Pb}$ stress alone visibly reduced the $\mathrm{Chl} \mathrm{a}, \mathrm{Chl} \mathrm{b}$, total $\mathrm{Chl}$, and carotenoid contents in the leaves of B. napus as compared to control.
Foliar applied ALA did not show any impact on Chl contents under $\mathrm{Pb}$ stress conditions; however, it significantly increased the total Chl contents by $11.88 \%$ under higher concentration of $\mathrm{Pb}(400 \mu \mathrm{M})$, as compared to its respective control. Moreover, the higher chlorophyll values were found under ALA alone conditions. The effects of different treatments of ALA and $\mathrm{Pb}$ on photosynthetic parameters have been presented in Figure 1. The data depicted that $\mathrm{Pb}$ toxicity significantly inhibited all the photosynthetic attributes, that is, net photosynthetic rate, stomatal conductance, internal $\mathrm{CO}_{2}$ concentration, and transpiration rate as compared to control, and this inhibition was recognized as dosedependent. Exogenous application of ALA alone exhibited a significant positive effect on stomatal conductance and transpiration rate of the rapeseed plants. The ALA at $25 \mathrm{mg}$ $\mathrm{L}^{-1}$ increased the net photosynthetic rate by $10.03 \%$ and $44.72 \%$, stomatal conductance by $33.33 \%$ and $41.93 \%$, internal $\mathrm{CO}_{2}$ concentration by $15.32 \%$ and $27.36 \%$, and transpiration rate by $53.57 \%$ and $74.02 \%$ under different levels of $\mathrm{Pb}(100$ and $400 \mu \mathrm{M}$, resp.) as compared to their respective controls.

\subsection{ALA Reduced Pb Uptake in Brassica Plants under Pb} Stress. $\mathrm{Pb}$ concentration was significantly enhanced in the shoots and roots of $B$. napus plants under $\mathrm{Pb}$ alone conditions (Table 4). The magnitude of $\mathrm{Pb}$ uptake was increased, as the $\mathrm{Pb}$ level increased in solution culture, and uptake of $\mathrm{Pb}$ contents was more in roots as compared to shoots under different $\mathrm{Pb}$ concentrations. Foliar spray of ALA significantly reduced the $\mathrm{Pb}$ contents in both shoots and roots under different $\mathrm{Pb}$ concentrations. The ALA at $25 \mathrm{mg} \mathrm{L}^{-1}$ reduced the $\mathrm{Pb}$ contents in shoots by $38.88 \%$ and $61.25 \%$ and in 


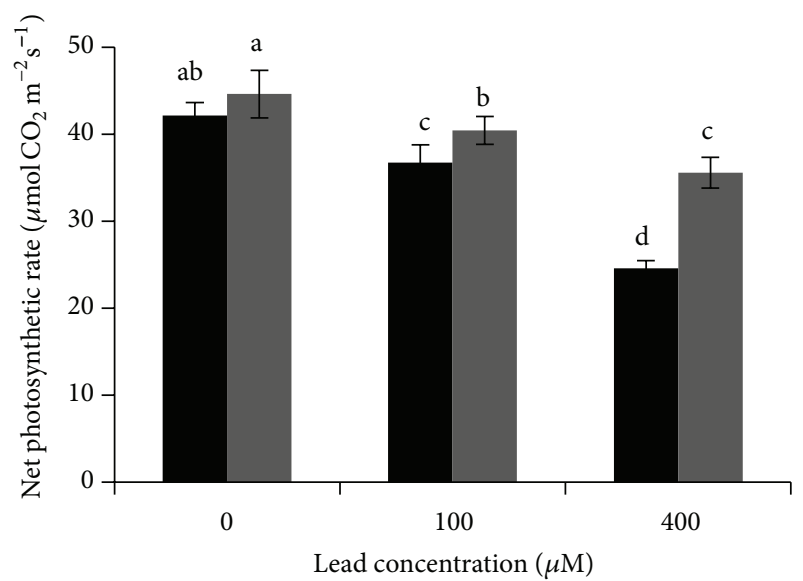

(a)

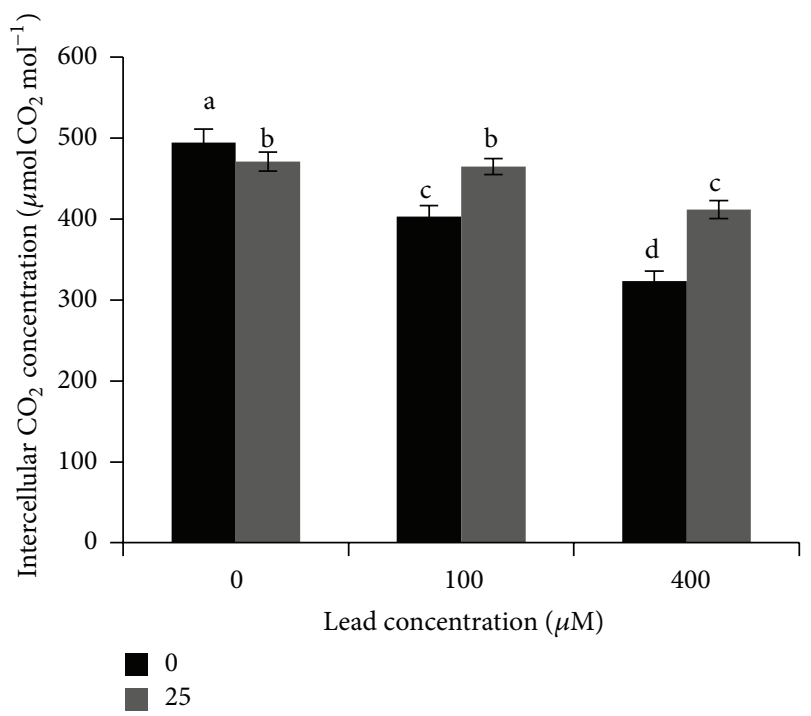

(c)

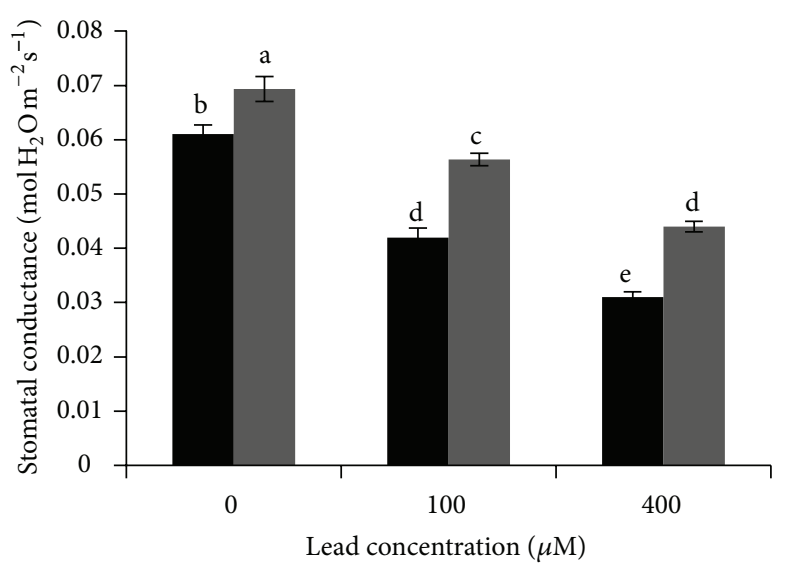

(b)

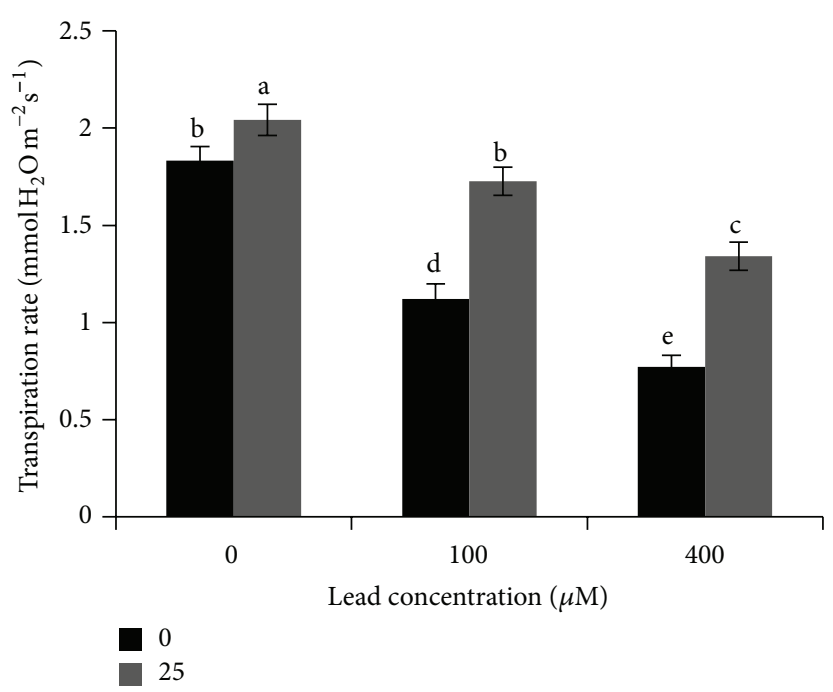

(d)

Figure 1: Effects of treatments of 5-aminolevulinic acid (ALA) $\left(0,25 \mathrm{mg} \mathrm{L}^{-1}\right)$ and lead (Pb) $(0,100$, and $400 \mu \mathrm{M})$ on (a) net photosynthetic rate, (b) stomatal conductance, (c) intercellular $\mathrm{CO}_{2}$ concentration, and (d) transpiration rate of the youngest fully expanded leaf in Brassica napus $\mathrm{cv}$. ZS 758. Values are means of eight readings \pm SD. Columns marked with the same lowercase letters are not significantly different by the LSD test at $P \leq 0.05$.

roots by $70.07 \%$ and $72.80 \%$ under different concentrations of $\mathrm{Pb}(100$ and $400 \mu \mathrm{M}$, resp.) as compared to their respective controls.

\subsection{ALA Alleviated the Pb-Induced Ultrastructural Changes.} Ultrastructural changes in leaf mesophyll and root tip cells of B. napus L. (cv. ZS 758) are demonstrated in Figures 2-5. The TEM micrographs of leaf mesophyll cells of ZS 758 at the control level (i.e., untreated) at low and high magnification are shown in Figures 2(a) and 2(b). There was clear chloroplast with smoothly packed granum and thylakoid membranes along with a number of starch granules. The cell wall and cell membrane were also clear and apparent. The cell also contained a clear nucleus with nucleolus and nuclear membrane. A whole mesophyll cell was observed at the level of $25 \mathrm{mg} \mathrm{L}^{-1}$
ALA alone as depicted in Figures 2(c) and 2(d). There were maximum intercellular spaces and all the organelles in the cells were clearly differentiated. A clear and well-developed cell wall and cell membrane could be observed in the micrographs. The nucleus was present with a nucleolus and a clear nuclear membrane. There was a well-developed chloroplast with packed granum and thylakoid membranes. The TEM micrographs of leaf mesophyll cells of ZS 758 at $\mathrm{Pb}(400 \mu \mathrm{M})$ alone at low and high magnification are shown in Figures 3(a) and 3(b). The higher concentration of $\mathrm{Pb}(400 \mu \mathrm{M})$ totally damaged the mesophyll cell and reduced the intercellular spaces between all the cells. The cell wall and cell membrane were fused to each other. The higher concentration of $\mathrm{Pb}$ totally damaged the thylakoid membranes of chloroplast. There were no more starch granules in the chloroplast as compared to controls. The changes in the fine structures of 


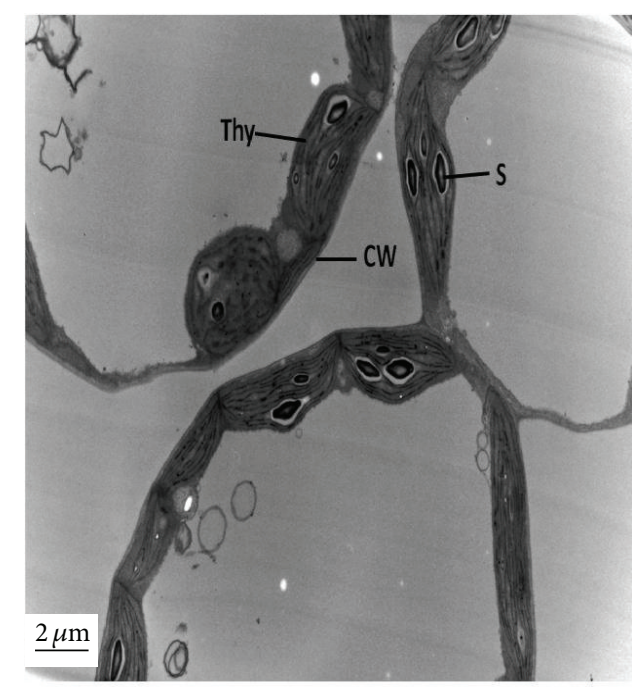

(a)

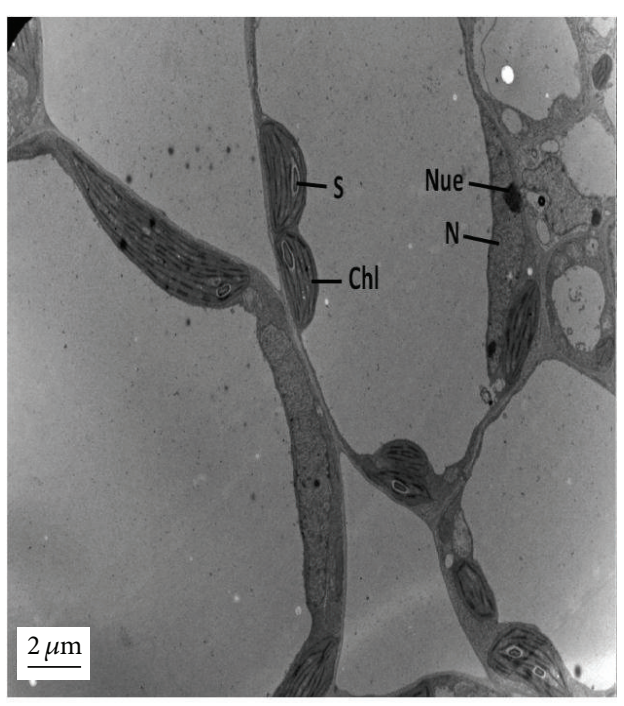

(c)

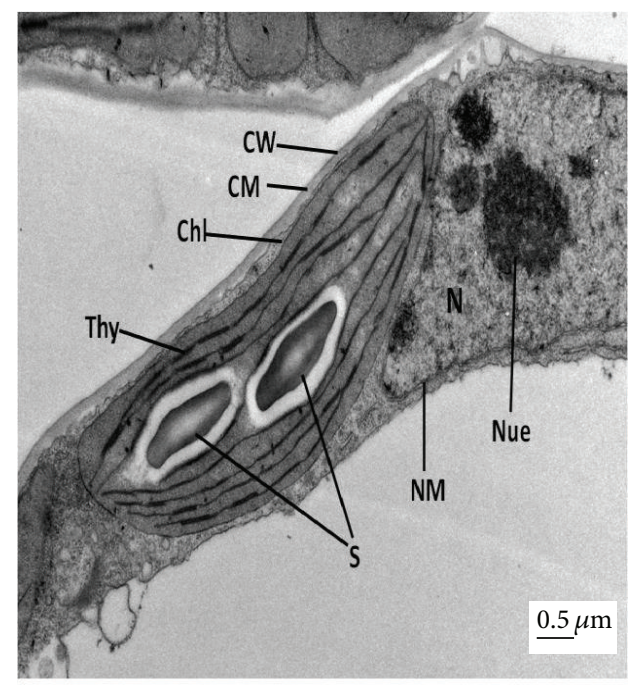

(b)

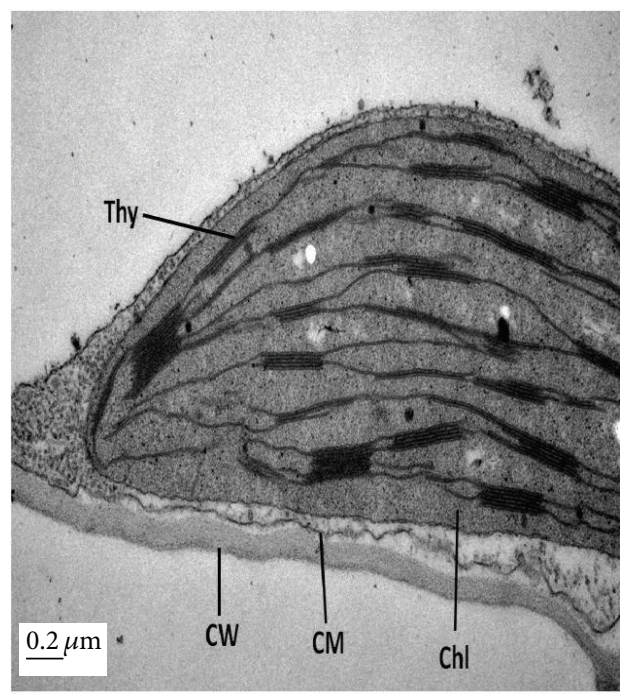

(d)

FIGURE 2: Electron micrographs of leaf mesophyll cells of 15-day hydroponically grown seedlings of Brassica napus cv. ZS 758. (a-b) TEM micrographs of mesophyll cells of leaves of ZS 758 at control level at low and high magnifications, respectively, show a clear cell wall (CW) and cell membrane (CM), well-developed chlorophyll (Chl) with thylakoids, grana, and starch grain (S). (c-d) TEM micrographs of mesophyll cells of ZS 758 at $25 \mathrm{mg} \mathrm{L}^{-1} 5$-aminolevulinic acid (ALA) alone at low and high magnifications, respectively, show a small nucleus (N) with developed nucleolus (Nue) and nuclear membrane (NM), well-developed chloroplast (Chl) with thylakoids, grana, and starch grains (S). Cell wall $(\mathrm{CW})$ and cell membrane $(\mathrm{CM})$ are present. Moreover, intercellular spaces are found.

leaf mesophyll cells due to foliar application of $25 \mathrm{mg} \mathrm{L}^{-1}$ ALA under $400 \mu \mathrm{M} \mathrm{Pb}$ have been highlighted in Figures 3(c) and $3(\mathrm{~d})$. The nucleus was well developed with a nuclear membrane and nucleolus. The intercellular spaces among the cells could be seen in the micrograph. The chloroplast was clear having a number of starch granules. Briefly, it was observed that a high dose of $\mathrm{Pb}$ ruptured the structures of all organelles and the starch granule was not present. The application of ALA decreased the drastic effect of $\mathrm{Pb}$ stress in the leaf ultrastructures of rapeseed plants in the present study.
The TEM of root cells of ZS 758 at control treatment with low and high magnifications have been shown in Figures 4(a) and 4(b). The micrograph showed a clear nucleus with nuclear membrane and nucleolus. Moreover, clear endoplasmic reticulum and mitochondria were found in root tip cell. The cell wall and cell membrane were smooth and continuous, and golgi bodies can also be observed in the micrograph. A big and round shape nucleus was observed with nucleolus and nuclear membrane at the level of $25 \mathrm{mg}$ $\mathrm{L}^{-1}$ ALA alone (Figures 4(c) and 4(d)). A well-developed mitochondria and endoplasmic reticulum were found in 


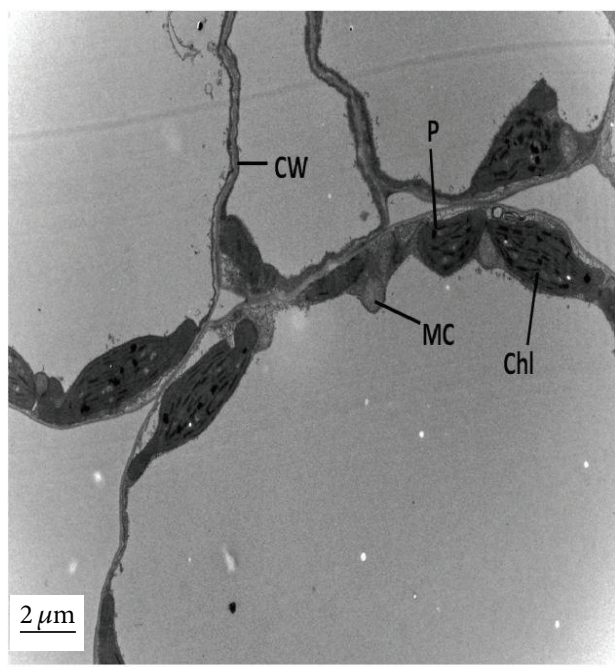

(a)

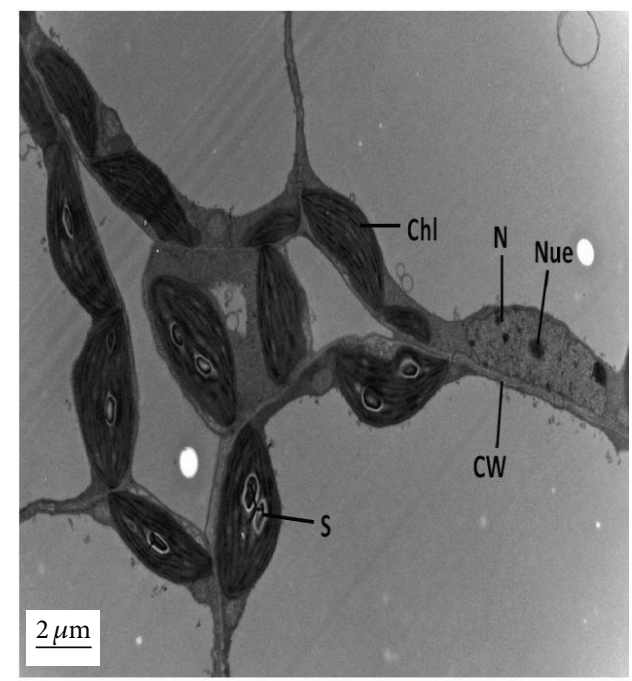

(c)

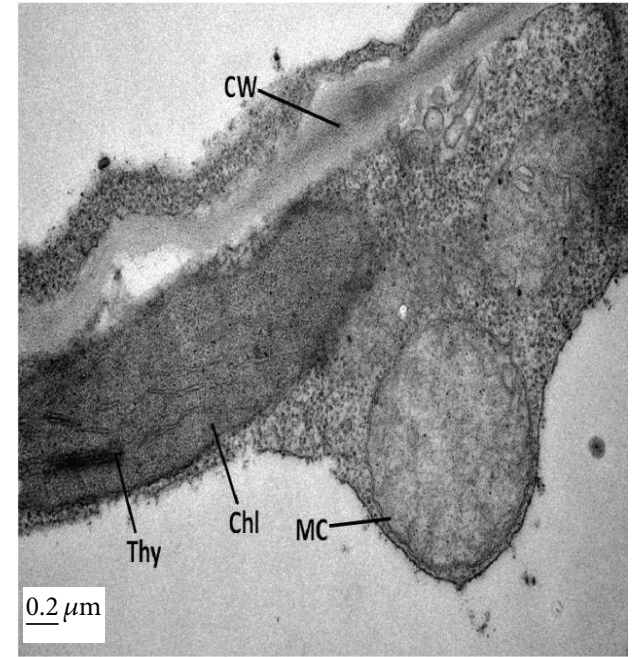

(b)

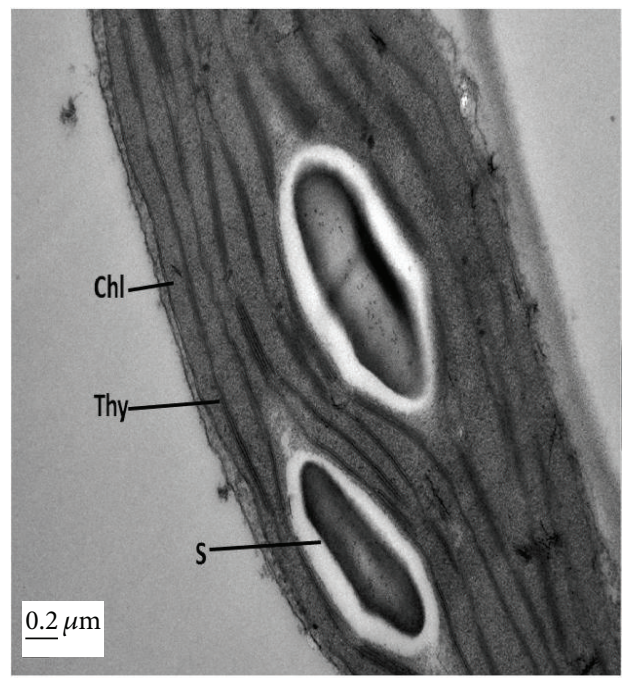

(d)

FIGURE 3: Electron micrographs of leaf mesophyll cells of 15-day hydroponically grown seedlings of Brassica napus cv. ZS 758. (a-b) TEM micrographs of mesophyll cells of ZS 758 under $400 \mu \mathrm{M}$ lead $(\mathrm{Pb})$ at low and high magnifications, respectively, show swollen and ruptured chloroplast (Chl) and absence of starch grain (S). Cell wall (CW) and cell membrane (CM) are diffused with each other and no nucleus was found. Moreover, accumulation of $\mathrm{Pb}$ is increased in the form of electron dense granules attached to the cell walls. (c-d) TEM micrographs of mesophyll cells of ZS 758 at $25 \mathrm{mg} \mathrm{L}^{-1} 5$-aminolevulinic acid (ALA) under $400 \mu \mathrm{M}$ lead (Pb) at low and high magnifications, respectively, show an elongated nucleus (N) with well developed nucleolus (Nue) and nuclear membrane (NM). Cell wall (CW) and cell membrane (CM) are clear. Chloroplast (Chl) is well-developed in almost round shape and has thylakoids, grana, and big starch grain (S).

micrographs. The TEM of root cells of ZS 758 at $\mathrm{Pb}(400 \mu \mathrm{M})$ alone at low and high magnification are shown in Figures 5 (a) and 5(b). Pb concentration at $400 \mu \mathrm{M}$ showed obvious ultrastructural changes as compared to control. There was an elongated nucleus with immature nucleolus. The cell wall and cell membrane were diffused into each other and mitochondrion was undeveloped. $\mathrm{Pb}$ was present in the form of small granules in the vacuole and along the cell wall. The changes in the fine structures of root tip cells due to foliar application of $25 \mathrm{mg} \mathrm{L}^{-1}$ ALA under $400 \mu \mathrm{M} \mathrm{Pb}$ have been depicted in Figures 5(c) and 5(d). There was well-developed nucleus with nuclear membrane in the cell. The ALA alleviated the $\mathrm{Pb}$ stress and presented clear mitochondria, cell wall, and golgi bodies in root tip cell.

\section{Discussion}

Lead $(\mathrm{Pb})$ is a highly phytotoxic heavy metal in the environment causing alteration in various physiological processes and ultrastructural changes in plants [7]. Generally, the sensitivity to heavy metal of a given plant depends on metal concentration, dose duration, plant variety and type, age of plant, and plant tissue being analyzed [25]. The present study was carried to analyze the beneficial role of 5-aminolevulinic 
TABLE 3: Effects of treatments of 5-aminolevulinic acid (ALA) $\left(\mathrm{mg} \mathrm{L}^{-1}\right)$ and lead $(\mathrm{Pb})(\mu \mathrm{M})$ on chlorophyll and carotenoids contents $\left(\mathrm{mg} \mathrm{g}^{-1}\right.$ FW) in the leaves of Brassica napus cv. ZS 758.

\begin{tabular}{cccccc}
\hline \multirow{2}{*}{ ALA conc. } & \multirow{2}{*}{ Pb conc. } & \multicolumn{4}{c}{ Mean values and their relative increase/decrease over respective controls } \\
& & Chlorophyll a & Chlorophyll b & Total chlorophyll & Carotenoids \\
\hline \multirow{3}{*}{0} & 0 & $47.92 \pm 2.56^{\mathrm{a}}(0)$ & $58.54 \pm 1.64^{\mathrm{b}}(0)$ & $106.47 \pm 1.87^{\mathrm{b}}(0)$ & $4.89 \pm 0.81^{\mathrm{ab}}(0)$ \\
& 100 & $44.45 \pm 1.98^{\mathrm{a}}(-7.24)$ & $58.31 \pm 1.51^{\mathrm{b}}(-0.39)$ & $102.76 \pm 3.50^{\mathrm{b}}(-3.74)$ & $4.87 \pm 0.59^{\mathrm{abc}}(0)$ \\
& 400 & $34.20 \pm 1.94^{\mathrm{b}}(-28.63)$ & $47.50 \pm 1.88^{\mathrm{d}}(-18.85)$ & $81.71 \pm 1.11^{\mathrm{d}}(-23.25)$ & $3.54 \pm 0.37^{\mathrm{c}}(-27.31)$ \\
\hline \multirow{3}{*}{25} & 0 & $47.48 \pm 2.25^{\mathrm{a}}(-0.91)$ & $64.93 \pm 1.76^{\mathrm{a}}(+10.91)$ & $112.42 \pm 4.01^{\mathrm{a}}(+5.58)$ & $5.43 \pm 0.60^{\mathrm{a}}(+11.49)$ \\
& 100 & $45.23 \pm 2.35^{\mathrm{a}}(+1.75)$ & $61.40 \pm 1.71^{\mathrm{b}}(+5.31)$ & $106.64 \pm 4.06^{\mathrm{b}}(+3.77)$ & $4.92 \pm 0.48^{\mathrm{ab}}(+1.02)$ \\
& 400 & $37.63 \pm 2.27^{\mathrm{b}}(+10.02)$ & $53.73 \pm 1.75^{\mathrm{c}}(+13.11)$ & $91.42 \pm 2.89^{\mathrm{c}}(+11.88)$ & $3.95 \pm 0.42^{\mathrm{bc}}(+11.58)$ \\
\hline
\end{tabular}

Values are the means of four replications \pm SD. Variants are significant at $P \leq 0.05$.

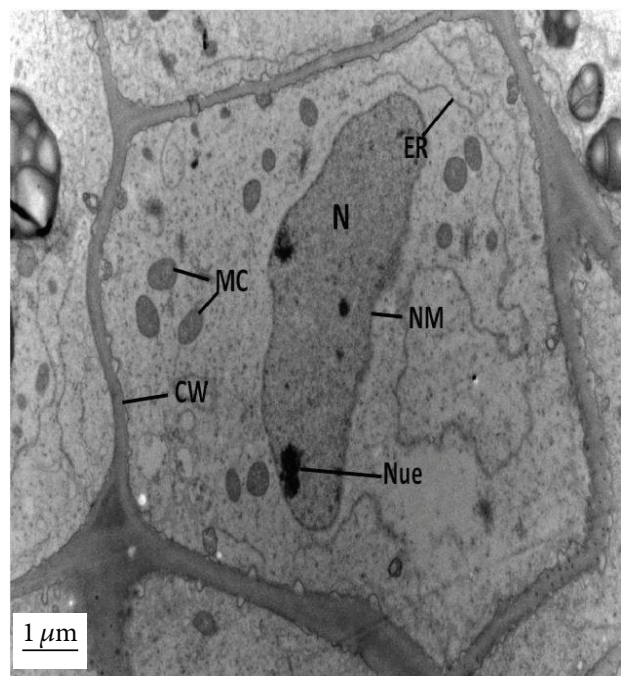

(a)

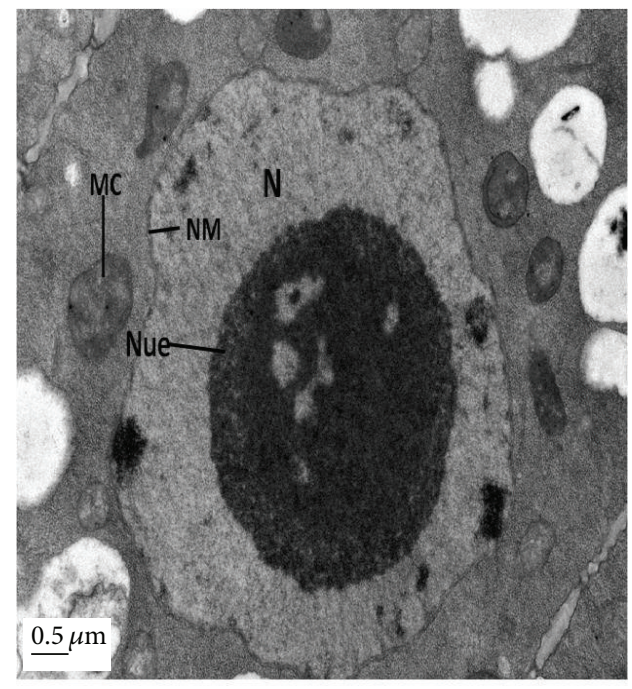

(c)

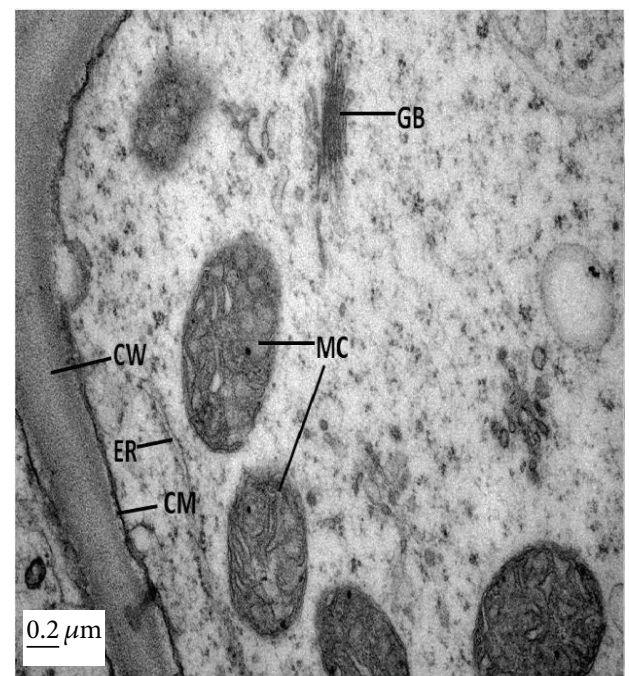

(b)

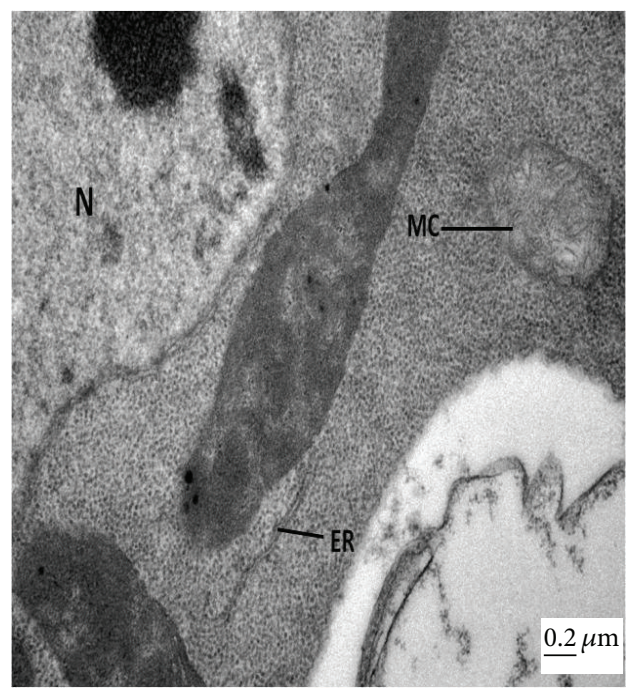

(d)

FIGURE 4: Electron micrographs of root tip cells of 15-day hydroponically grown seedlings of Brassica napus cv. ZS 758. (a-b) TEM micrographs of root tip cells of ZS 758 at control level at low and high magnifications, respectively, show well-developed nucleus (N) with nucleolus, smooth cell wall (CW), clear endoplasmic reticulum (ER), golgi bodies (GB), and well-developed mitochondria (MC). (c-d) TEM micrographs of root tip cells of ZS 758 at $25 \mathrm{mg} \mathrm{L}^{-1}$ 5-aminolevulinic acid (ALA) alone at low and high magnifications, respectively, show a clear cell with well-developed nucleus $(\mathrm{N})$ with nucleoli (Nue) and a distinct nuclear membrane, a number of well-developed mitochondria (MC), and continuous endoplasmic reticulum (ER). 
acid (ALA) on oilseed B. napus plants under Pb stress. The present results demonstrated that $\mathrm{Pb}$ toxicity visibly inhibited the plant growth parameters (Table 1). The reduction in plant growth would be the adverse effect of $\mathrm{Pb}$ on physiological processes and disturbance in plant mineral nutritional status. Moreover, reduction in root growth might be due to $\mathrm{Pb}$ induced inhibition of cell division in root cell [7]. On the other hand, plant growth was improved under the combined treatment of ALA and $\mathrm{Pb}$ stress (Table 1). This increase in growth with ALA might be due to the fact that ALA has a promotive role in regulating different metabolic processes, thereby improving growth and yield of most plants under abiotic stresses [26]. Recently, it has been recognized that ALA enhanced the plant growth by alleviating cadmium effects in B. napus [12].

The data showed that $\mathrm{Pb}$ toxicity significantly reduced the root morphology of plants (Table 2). The possible reason behind is that $\mathrm{Pb}$ toxicity leads to the imbalance of water status and disturbed nutrient uptake and inhibits the cell division in the root tip cell [7]. Previously, it was observed that $\mathrm{Pb}$ toxicity demoted the root morphology in two ecotypes of Elsholtzia argyi [3]. Schwarz and Grosch [27] also conducted similar studies to discover the effects of $\mathrm{Pb}$ on the relationship between yield and root morphology. Meanwhile, when plant sustained foliar application of ALA, it significantly improved the root morphology of $B$. napus plants under the $\mathrm{Pb}$ stress (Table 2). This improvement in root morphology under the application of ALA might be due to the fact that ALA activates the heme-based antioxidant systems (APX, POD, and CAT) to scavenge the reactive oxygen species like $\mathrm{H}_{2} \mathrm{O}_{2}[18,28]$. Moreover, this study showed that $\mathrm{Pb}$ stress alone reduced the chlorophyll contents (Table 3 ) and photosynthetic parameter as compared to control (Figure 1). This reduction in photosynthetic attributes might be due to the destruction of protein complex, chloroplast, and photosynthetic apparatus under metal stress [29], and at the same time heavy metal stress might inhibit the photosynthetic electron transport chain [30]. Moreover, decomposition of chlorophyll might be due to increase in chlorophyllase activity under heavy metal stress [31]. It has been well documented in the literature that heavy metals can affect stomatal conductance, gas exchange, and chlorophyll contents, thereby affecting the net photosynthetic rate [32]. At the same time, increase in chlorophyll and net photosynthesis rate with foliar application of ALA confirms that ALA performs as growth regulator and enhances the parameters involved in photosynthesis. The role of ALA in improving photosynthetic attributes can therefore be due to the significant improvement in Chl content [33] and subsequently increasing light harvesting capacities in the treated plants. Ali et al. [12] found that foliar application of ALA significantly elevated the photosynthetic parameters in B. napus plants under cadmium stress conditions.

The results showed that $\mathrm{Pb}$ contents were increased in different plant parts with increasing $\mathrm{Pb}$ concentration in the medium (Table 4). These results about more uptake of $\mathrm{Pb}$ contents in roots than shoots express the capability of plants to avoid metal-induced changes [34]. In this study, it was found that foliar application of ALA reduced the uptake of $\mathrm{Pb}$ in different parts of plants under $\mathrm{Pb}$ stress. It may be due to the application of ALA which strengthens the plant defense system by activating antioxidant machinery, thus prevents the uptake or movement of heavy metal in plant tissues $[12,13]$. So, it can be suggested that exogenous ALA could be applied for the purpose of phytoextraction.

Microscopic examination was performed as it helped to study the changes at cellular level [35]. In the present study, plant mesophyll cell and root tip cells were significantly damaged under the $\mathrm{Pb}$ toxicity alone conditions. It was advocated that chloroplasts are highly susceptible to oxidative stress [36]. In mesophyll cell, $\mathrm{Pb}$-induced stress brought about the disappearance of starch granules inside the chloroplast and dissolved thylakoids membranes (Figures 3(a) and 3(b)). Under $\mathrm{Pb}$ stress, metal deposition was present in vacuoles and cell walls and all the organelles were totally damaged in root tip cells (Figures 5(a) and 5(b)). Previously, similar ultrastructural disorders in plant cells were noticed under heavy metal stress [37]. However, foliar application of ALA improved these structures under $\mathrm{Pb}$ toxicity in both mesophyll cell (Figures 3(c) and 3(d)) and root tip cell (Figures 5(c) and 5(d)). Improved cell structures with foliar application of ALA under Pb-treated plants could be the indication of less oxidative stress and might be due to that ALA helped in inducing the antioxidant system in the thylakoids and cell membranes. The higher activity of ascorbic peroxidases catalyzed the breakdown of $\mathrm{H}_{2} \mathrm{O}_{2}$ in Halliwell-Asada pathway originally described in the chloroplast [38]. So, it can be suggested that activity of ascorbic peroxidases can potentially protect thylakoids from activated oxygen species under the Cd stress. Naeem et al. [39] and Ali et al. [13, 18] also observed that ALA improved the cell structures in B. napus under the salinity and cadmium stress, respectively. Previously, Castelfranco and Jones [40] suggested that ALA showed alleviating role to trigger the heme-based molecules. It can be concluded that ALA may alleviate oxidative stress induced by $\mathrm{Pb}$ toxicity. From the present findings, it could be suggested that ALA ameliorated the $\mathrm{Pb}$-induced inhibition of plant growth, photosynthesis, and ultrastructural changes in plant cells.

\section{Conclusions}

According to the present study, we observed that $\mathrm{Pb}$ reduced the plant growth and root morphology as well as damaged the cell ultrastructures. Meanwhile, exogenously applied ALA increased the plant growth and improved cell ultrastructures under the $\mathrm{Pb}$ toxicity. Overall, results from present research reveal that ALA has the ability to get rid of the adverse effects of $\mathrm{Pb}$ on $B$. napus by increasing plant growth and net photosynthesis rate and improving the ultrastructural changes induced by $\mathrm{Pb}$ stress. To examine the precise ameliorative role of ALA under $\mathrm{Pb}$ stress conditions a soil environment-based approach is needed.

\section{Conflict of Interests}

The authors declare that there is no conflict of interests regarding the publication of this paper. 
TABLE 4: Effects of treatments of 5-aminolevulinic acid (ALA) $\left(\mathrm{mg} \mathrm{L}^{-1}\right)$ and lead $(\mathrm{Pb})(\mu \mathrm{M})$ on $\mathrm{Pb}$ contents in shoots and roots of Brassica napus cv. ZS 758.

\begin{tabular}{|c|c|c|c|}
\hline ALA conc. & $\mathrm{Pb}$ conc. & Shoot $\left(\mathrm{mg} \mathrm{kg}^{-1} \mathrm{DW}\right)$ & $\operatorname{Root}\left(\mathrm{mg} \mathrm{kg}^{-1} \mathrm{DW}\right)$ \\
\hline \multirow{3}{*}{0} & 0 & $0.34 \pm 0.01^{\mathrm{e}}$ & $0.65 \pm 0.03^{\mathrm{d}}$ \\
\hline & 100 & $144.84 \pm 9.50^{c}$ & $756.44 \pm 8.67^{b}$ \\
\hline & 400 & $461.79 \pm 13.02^{\mathrm{a}}$ & $2741.12 \pm 16.90^{\mathrm{a}}$ \\
\hline \multirow{3}{*}{25} & 0 & $0.27 \pm 0.01^{\mathrm{e}}$ & $0.73 \pm 0.02^{\mathrm{d}}$ \\
\hline & 100 & $88.58 \pm 7.14^{\mathrm{d}}$ & $226.35 \pm 13.14^{\mathrm{c}}$ \\
\hline & 400 & $178.93 \pm 15.35^{\mathrm{b}}$ & $745.54 \pm 9.50^{\mathrm{b}}$ \\
\hline
\end{tabular}

Values are the means of four replications \pm SD. Variants are significant at $P \leq 0.05$.

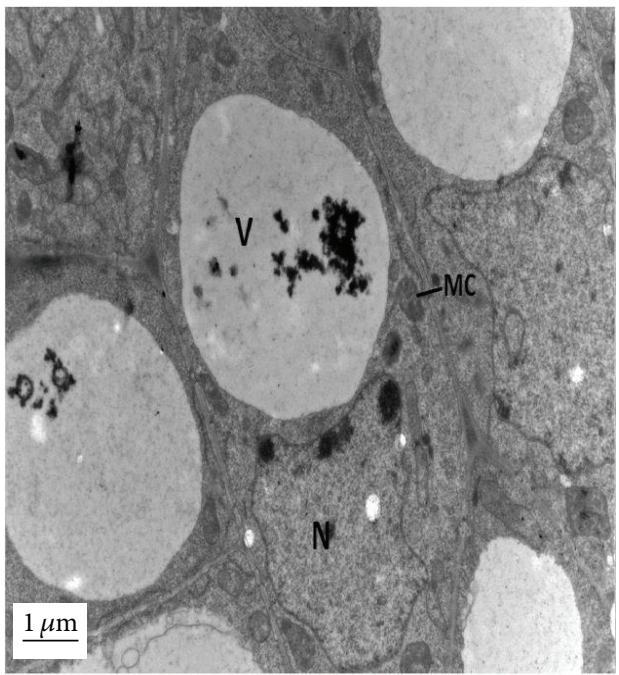

(a)

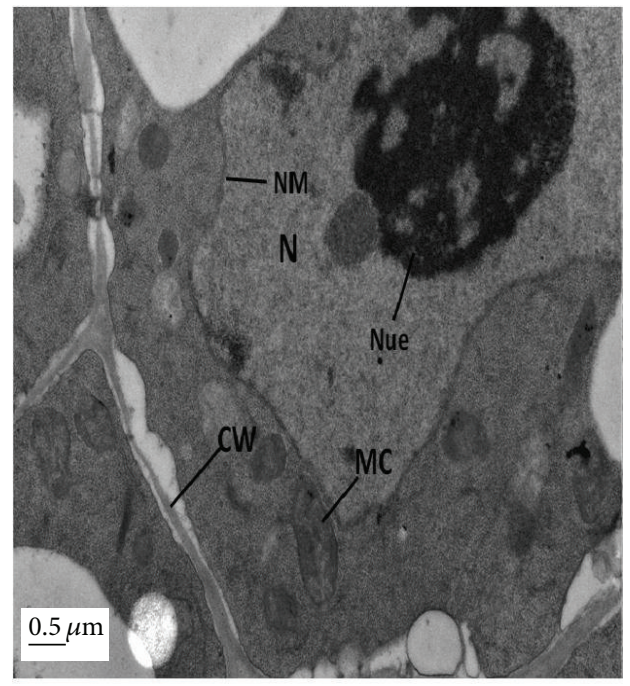

(c)

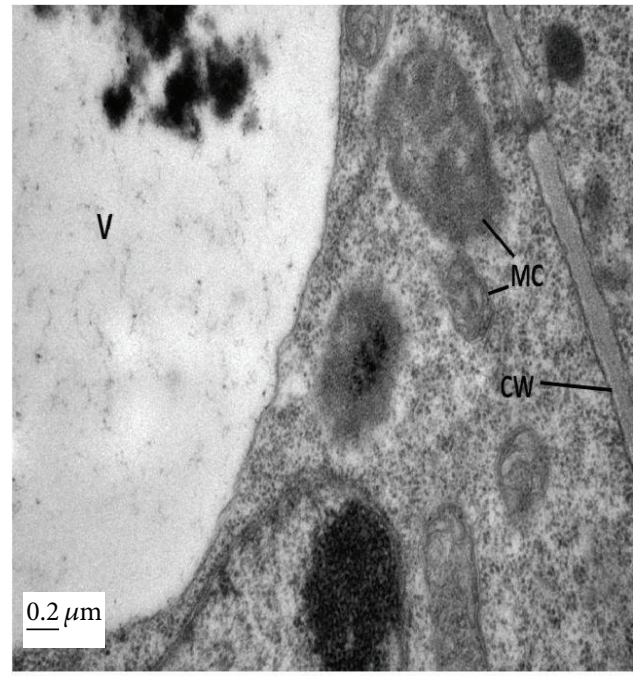

(b)

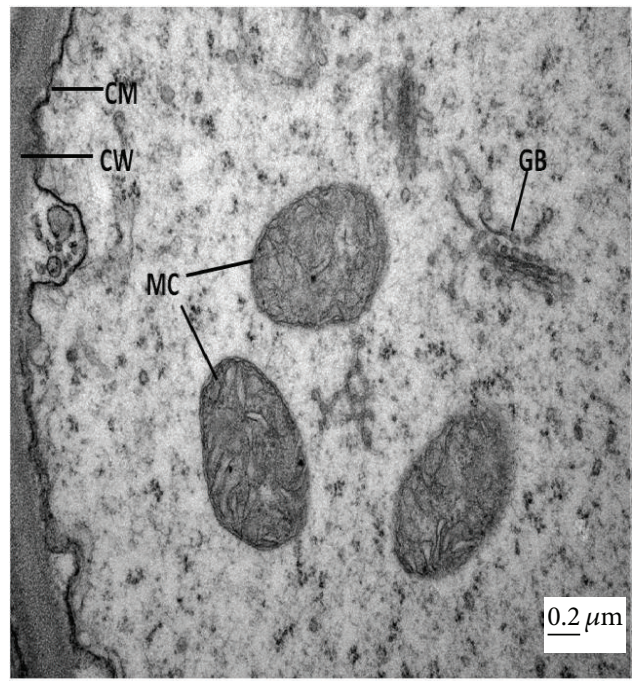

(d)

FIGURE 5: Electron micrographs of root tip cells of 15 day-hydroponically grown seedlings of Brassica napus cv. ZS 758. (a-b) TEM micrographs of root tip cells of ZS 758 at $400 \mu \mathrm{M} \mathrm{Pb}$ alone at low and high magnifications, respectively, show undeveloped nucleus (N) with broken nuclear membrane (NM), undeveloped mitochondria (MC), disappearance of endoplasmic reticulum (ER), and cracked cell wall (CW). Moreover, $\mathrm{Pb}$ accumulation increased in the form of electron dense granules along the cell wall and vacuole (V). (c-d) TEM micrographs of root tip cells of ZS 758 at $25 \mathrm{mg} \mathrm{L}^{-1}$ 5-aminolevulinic acid (ALA) under $400 \mu \mathrm{M} \mathrm{Pb}$ concentration at low and high magnifications, respectively, show a clear cell with big nucleus $(\mathrm{N})$, number of developed mitochondria (MC), golgi bodies (GB), and cell wall (CW). 


\section{Authors' Contribution}

Tian Tian and Basharat Ali contributed equally to this work.

\section{Acknowledgments}

This work was supported by the National High Technology Research and Development Program of China (2011AA10A206, 2013AA103007), the National Key Science and Technology Supporting Program of China (2010BAD01B04), the National Natural Science Foundation of China (31170405), and the Science and Technology Department of Zhejiang Province (2012C12902-1, 2011R50026 $-5)$.

\section{References}

[1] M. J. Eick, J. D. Peak, P. V. Brady, and J. D. Pesek, "Kinetics of lead adsorption/desorption on goethite: residence time effect," Soil Science, vol. 164, no. 1, pp. 28-39, 1999.

[2] A. Piechalak, B. Tomaszewska, and D. Barałkiewicz, "Enhancing phytoremediative ability of Pisum sativum by EDTA application," Phytochemistry, vol. 64, no. 7, pp. 1239-1251, 2003.

[3] E. Islam, X. Yang, T. Li, D. Liu, X. Jin, and F. Meng, "Effect of $\mathrm{Pb}$ toxicity on root morphology, physiology and ultrastructure in the two ecotypes of Elsholtzia argyi," Journal of Hazardous Materials, vol. 147, no. 3, pp. 806-816, 2007.

[4] J. A. Arias, J. R. Peralta-Videa, J. T. Ellzey, M. Ren, M. N. Viveros, and J. L. Gardea-Torresdey, "Effects of Glomus deserticola inoculation on Prosopis: enhancing chromium and lead uptake and translocation as confirmed by X-ray mapping, ICP-OES and TEM techniques," Environmental and Experimental Botany, vol. 68 , no. 2, pp. 139-148, 2010.

[5] E. Islam, D. Liu, T. Li et al., "Effect of Pb toxicity on leaf growth, physiology and ultrastructure in the two ecotypes of Elsholtzia argyi," Journal of Hazardous Materials, vol. 154, no. 1-3, pp. $914-$ 926, 2008.

[6] E. Romanowska, B. Wróblewska, A. Drozak, and M. Siedlecka, "High light intensity protects photosynthetic apparatus of pea plants against exposure to lead," Plant Physiology and Biochemistry, vol. 44, no. 5-6, pp. 387-394, 2006.

[7] P. Sharma and R. S. Dubey, "Lead toxicity in plants," Brazilian Journal of Plant Physiology, vol. 17, no. 1, pp. 35-52, 2005.

[8] Z.-T. Xiong, F. Zhao, and M.-J. Li, "Lead toxicity in Brassica pekinensis Rupr.: effect on nitrate assimilation and growth," Environmental Toxicology, vol. 21, no. 2, pp. 147-153, 2006.

[9] W. Jiang and D. Liu, "Pb-induced cellular defense system in the root meristematic cells of Allium sativum L," BMC Plant Biology, vol. 10, article 40, 2010.

[10] M. Krzesłowska, M. Lenartowska, E. J. Mellerowicz, S. Samardakiewicz, and A. Woźny, "Pectinous cell wall thickenings formation-a response of moss protonemata cells to lead," Environmental and Experimental Botany, vol. 65, no. 1, pp. 119131, 2009.

[11] Z. J. Zhang, H. Z. Li, W. J. Zhou, Y. Takeuchi, and K. Yoneyama, "Effect of 5-aminolevulinic acid on development and salt tolerance of potato (Solanum tuberosum L.) microtubers in vitro," Plant Growth Regulation, vol. 49, no. 1, pp. 27-34, 2006.
[12] B. Ali, B. Wang, S. Ali et al., "5-Aminolevulinic acid ameliorates the growth, photosynthetic gas exchange capacity and ultrastructural changes under cadmium stress in Brassica napus L," Journal of Plant Growth Regulation, vol. 32, pp. 604-614, 2013.

[13] B. Ali, C. R. Huang, Z. Y. Qi et al., "5-Aminolevulinic acid ameliorates cadmium-induced morphological, biochemical and ultrastructural changes in seedlings of oilseed rape," Environmental Science and Pollution Research, vol. 72, pp. 7256-7267, 2013.

[14] W. F. Zhang, F. Zhang, R. Raziuddin et al., "Effects of 5aminolevulinic acid on oilseed rape seedling growth under herbicide toxicity stress," Journal of Plant Growth Regulation, vol. 27, no. 2, pp. 159-169, 2008.

[15] L.-J. Wang, W.-B. Jiang, H. Liu, W.-Q. Liu, L. Kang, and X.L. Hou, "Promotion by 5-aminolevulinic acid of germination of pakchoi (Brassica campestris ssp. chinensis var. communis Tsen et Lee) seeds under salt stress," Journal of Integrative Plant Biology, vol. 47, no. 9, pp. 1084-1091, 2005.

[16] M. S. Naeem, Z. L. Jin, G. L. Wan et al., "5-Aminolevulinic acid improves photosynthetic gas exchange capacity and ion uptake under salinity stress in oilseed rape (Brassica napus L.)," Plant and Soil, vol. 332, no. 1, pp. 405-415, 2010.

[17] M. O. Senge, "Recent advances in the biosynthesis and chemistry of chlorophylls," Photochemistry and Phytobiology, vol. 57, pp. 189-206, 1993.

[18] B. Ali, Q. J. Tao, Y. F. Zhou et al., "5-Aminolevolinic acid mitigates the cadmium-induced changes in Brassica napus as revealed by the biochemical and ultra-structural evaluation of roots," Ecotoxicology and Environmental Safety, vol. 92, pp. 271280, 2013.

[19] D. I. Arnon and D. R. Hoagland, "Crop production in artificial solution with special reference to factors affecting yield and absorption of inorganic nutrients," Soil Science, vol. 50, pp. 463$485,1940$.

[20] H. M. Hull, H. L. Morton, and J. R. Wharrie, "Environmental influences on cuticle development and resultant foliar penetration," The Botanical Review, vol. 41, no. 4, pp. 421-452, 1975.

[21] W. Zhou and M. Leul, "Uniconazole-induced alleviation of freezing injury in relation to changes in hormonal balance, enzyme activities and lipid peroxidation in winter rape," Plant Growth Regulation, vol. 26, no. 1, pp. 41-47, 1998.

[22] R. J. Porra, W. A. Thompson, and P. E. Kriedemann, "Determination of accurate extinction coefficients and simultaneous equations for assaying chlorophylls a and b extracted with four different solvents: verification of the concentration of chlorophyll standards by atomic absorption spectroscopy," Biochimica et Biophysica Acta, vol. 975, no. 3, pp. 384-394, 1989.

[23] Z. F. Pei, D. F. Ming, D. Liu et al., "Silicon improves the tolerance to water-deficit stress induced by polyethylene clycol in wheat (Triticum aestivum L.) seedlings," Journal of Plant Growth Regulation, vol. 29, no. 1, pp. 106-115, 2010.

[24] Y. T. Hsu and C. H. Kao, "Role of abscisic acid in cadmium tolerance of rice (Oryza sativa L.) seedlings," Plant, Cell and Environment, vol. 26, no. 6, pp. 867-874, 2003.

[25] Y. Gao, C. Miao, L. Mao, P. Zhou, Z. Jin, and W. Shi, "Improvement of phytoextraction and antioxidative defense in Solanum nigrum L. under cadmium stress by application of cadmiumresistant strain and citric acid," Journal of Hazardous Materials, vol. 181, no. 1-3, pp. 771-777, 2010.

[26] N. A. Akram, M. Ashraf, and F. Al-Qurainy, "Aminolevulinic acid-induced regulation in some key physiological attributes 
and activities of antioxidant enzymes in sunflower (Helianthus annuus L.) under saline regimes," Scientia Horticulturae, vol. 142, pp. 143-148, 2012.

[27] D. Schwarz and R. Grosch, "Influence of nutrient solution concentration and a root pathogen on tomato root growth and morphology," Scientia Horticulturae, vol. 97, no. 2, pp. 109-120, 2003.

[28] E. Nishihara, K. Kondo, M. M. Parvez, K. Takahashi, K. Watanabe, and K. Tanaka, "Role of 5-aminolevulinic acid (ALA) on active oxygen-scavenging system in NaCl-treated spinach (Spinacia oleracea)," Journal of Plant Physiology, vol. 160, no. 9, pp. 1085-1091, 2003.

[29] A. Vassilev, I. Iordanov, E. Chakalova, and V. Kerin, "Effect of cadmium stress on growth and photosynthesis of young barley (H. vulgare L.) plants. 2. Structural and functional changes in the photosynthetic apparatus," Bulgarian Journal of Plant Physiology, vol. 21, pp. 12-21, 1995.

[30] N. Mohanty, I. Vass, and S. Demeter, "Impairment of photosystem 2 activity at the level of secondary quinone electron acceptor in chloroplasts treated with cobalt, nickel and zinc ions," Physiolgia Plantarum, vol. 76, no. 3, pp. 386-390, 1989.

[31] A. Hegedüs, S. Erdei, and G. Horváth, "Comparative studies of $\mathrm{H}_{2} \mathrm{O}_{2}$ detoxifying enzymes in green and greening barley seedlings under cadmium stress," Plant Science, vol. 160, no. 6, pp. 1085-1093, 2001.

[32] T. I. Balakhnina, A. A. Kosobryukhov, A. A. Ivanov, and V. D. Kreslavskii, "The effect of cadmium on $\mathrm{CO}_{2}$ exchange, variable fluorescence of chlorophyll, and the level of antioxidant enzymes in pea leaves," Russian Journal of Plant Physiology, vol. 52, no. 1, pp. 15-20, 2005.

[33] L. J. Wang, W. B. Jiang, and B. J. Huang, "Promotion of 5 -aminolevulinic acid on photosynthesis of melon (Cucumis melo) seedlings under low light and chilling stress conditions," Physiologia Plantarum, vol. 121, no. 2, pp. 258-264, 2004.

[34] U. Najeeb, G. Jilani, S. Ali, M. Sarwar, L. Xu, and W. Zhou, "Insights into cadmium induced physiological and ultrastructural disorders in Juncus effusus L. and its remediation through exogenous citric acid," Journal of Hazardous Materials, vol. 186, no. 1, pp. 565-574, 2011.

[35] M. Caasi-Lit, M. I. Whitecross, M. Nayudu, and G. J. Tanner, "UV-B irradiation induces differential leaf damage, ultrastructural changes and accumulation of specific phenolic compounds in rice cultivars," Australian Journal of Plant Physiology, vol. 24 , no. 3, pp. 261-274, 1997.

[36] G. Q. Zhang, W. J. Zhou, H. H. Gu, W. J. Song, and E. J. J. Momoh, "Plant regeneration from the hybridization of Brassica juncea and B. napus through embryo culture," Journal of Agronomy and Crop Science, vol. 189, no. 5, pp. 347-350, 2003.

[37] M. K. Daud, Y. Sun, M. Dawood et al., "Cadmium-induced functional and ultrastructural alterations in roots of two transgenic cotton cultivars," Journal of Hazardous Materials, vol. 161, no. 1, pp. 463-473, 2009.

[38] Y. Nakano and K. Asada, "Hydrogen peroxide is scavenged by ascorbate-specific peroxidase in spinach chloroplasts," Plant and Cell Physiology, vol. 22, no. 5, pp. 867-880, 1981.

[39] M. S. Naeem, H. Warusawitharana, H. Liu et al., "5Aminolevulinic acid alleviates the salinity-induced changes in Brassica napus as revealed by the ultrastructural study of chloroplast," Plant Physiology and Biochemistry, vol. 57, pp. 8492, 2012.
[40] P. A. Castelfranco and O. T. G. Jones, "Protoheme turnover and chlorophyll synthesis in greening barley tissue," Plant Physiology, vol. 55, pp. 485-490, 1975. 

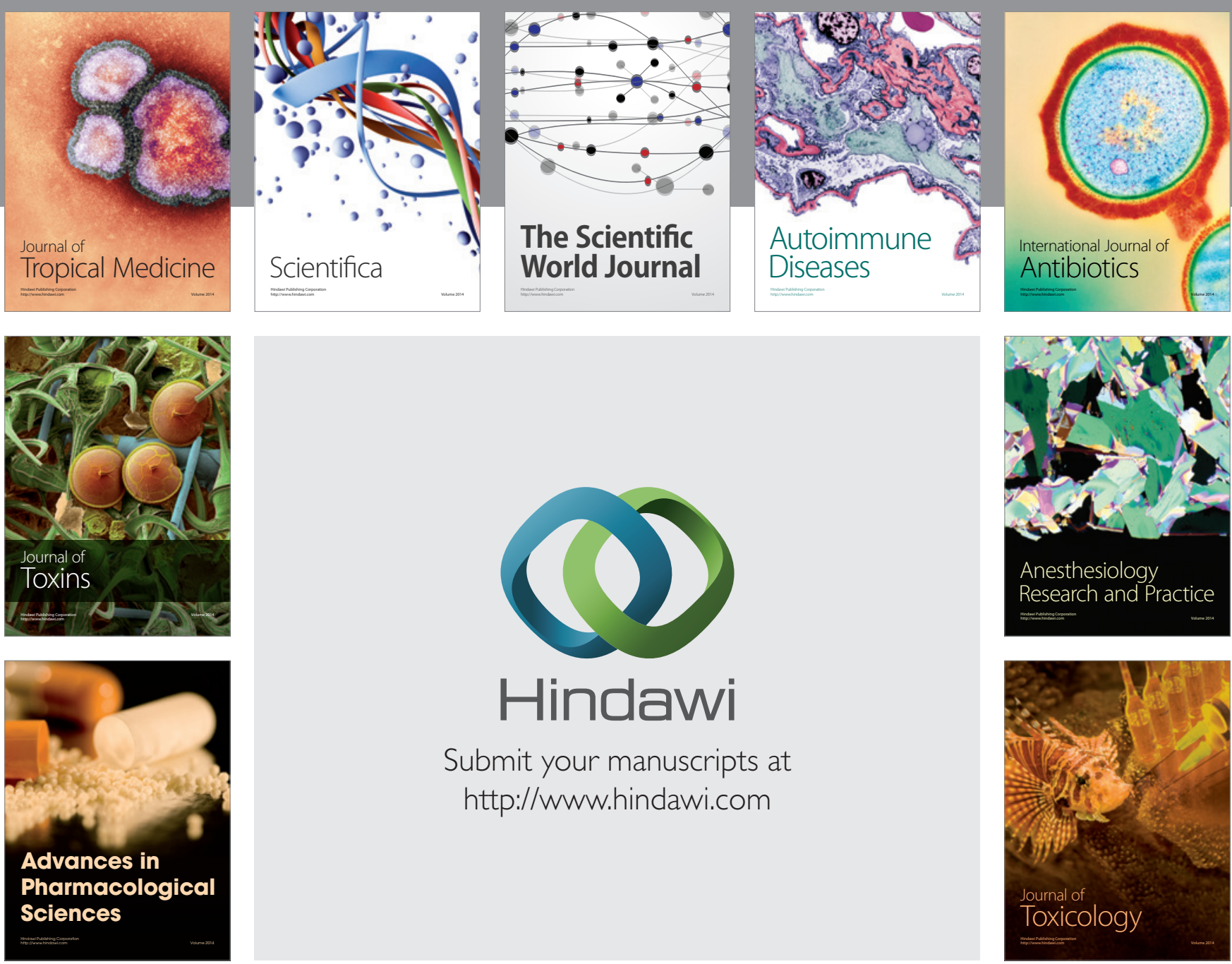

\section{Hindawi}

Submit your manuscripts at

http://www.hindawi.com
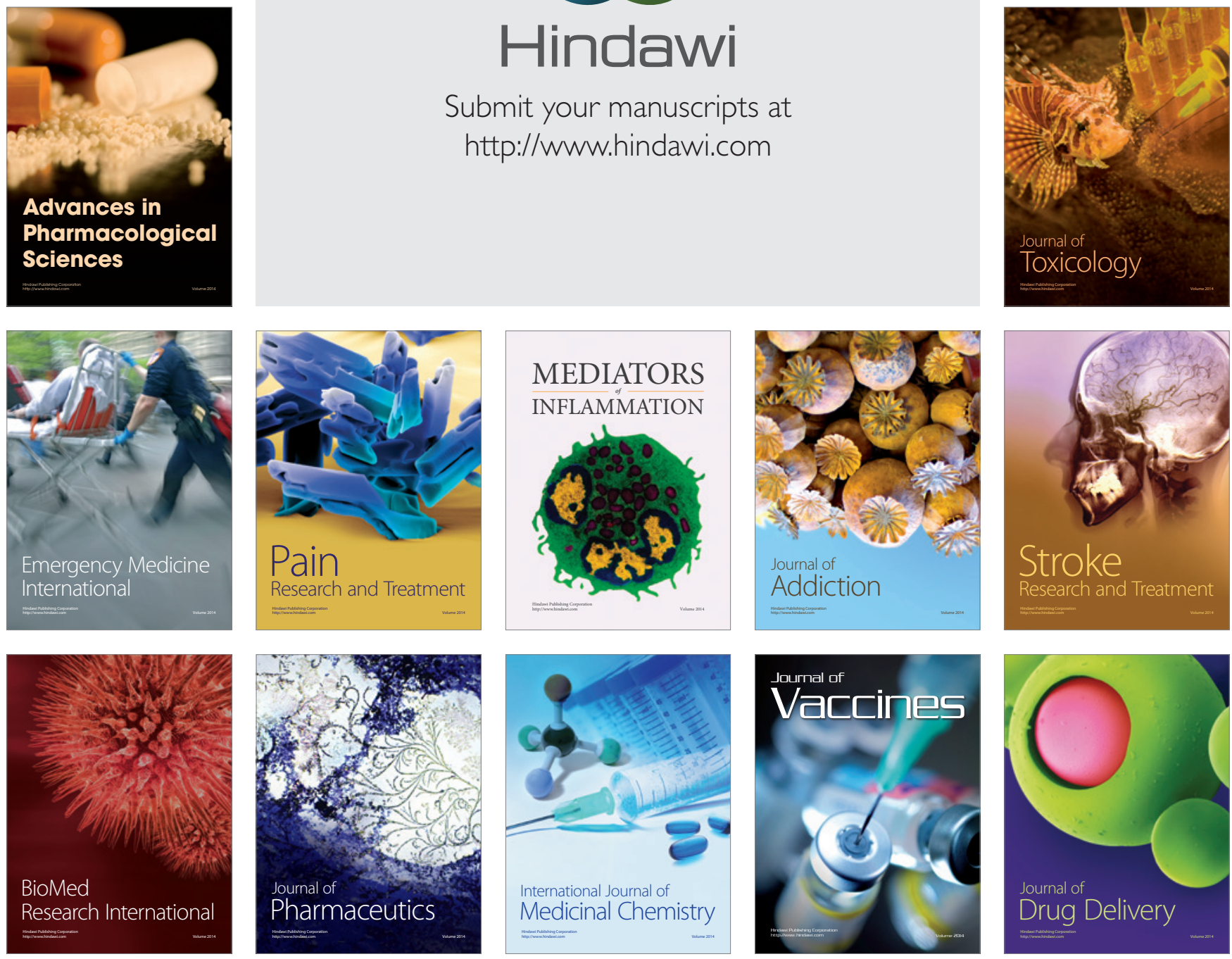